\title{
KAJIAN HAK KEKAYAAN INTELEKTUAL KARYA PERAJIN BATIK STUDI KASUS DI DESA WUKIRSARI IMOGIRI BANTUL
}

\author{
Setiati Widihastuti dan Eny Kusdarini \\ Universitas Negeri Yogyakarta \\ e-mail: setiatiwidiastuti@yahoo.com
}

\begin{abstract}
Abstrak: Kajian Hak Kekayaan Intelektual Karya Perajin Batik Studi Kasus di Desa Wukirsari Imogiri Bantul. Kajian ini bertujuan untuk mengetahui hak kekayaan intelektual yang dapat diberikan pada karya perajin batik Imogiri, kendalakendala yang ditemukan dalam memberikan perlindungan hak kekayaan intelektual pada karya perajin batik Imogiri, serta usaha-usaha yang telah dilakukan untuk mengatasi kendala-kendala tersebut. Sebagai suatu penelitian deskriptif dengan pendekatan kualitatif, wawancara, osbervasi, dan dokumentasi dipilih sebagai teknik pengumpulan data. Subjek penelitian berjumlah tujuh orang yang ditentukan dengan teknik snow ball. Analisis datanya berupa analisis domain, analisis taksonomis, analisis komponensial, dan analisis tema. Simpulan kajian ini adalah bahwa hak atas kekayaan intelektual (HKI) yang dapat dipergunakan untuk melindungi karya perajin batik Imogiri adalah: 1) hak cipta; 2) hak paten sederhana; 3) hak merek; dan 4) hak indikasi geografis. Adapun kendala dalam pemberian perlindungan HKI atas karya perajin batik Imogiri adalah: 1) terbatasnya pengetahuan dan pemahaman para perajin batik Imogiri tentang HKI; 2) kentalnya budaya kebersamaan membuat para perajin sangat sulit menerima konsep-konsep HKI yang menonjolkan hak-hak pribadi; 3) ketentuan-ketentuan dalam HKI yang bersifat komersial dan berorientasi pada keuntungan ekonomis tidak sesuai dengan nilai-nilai yang dimiliki para perajin; dan 4) mahalnya biaya dan sulitnya prosedur pengurusan HKI.
\end{abstract}

Kata Kunci: Hak kekayaan inteletual, karya batik, perempuan perajin batik

\begin{abstract}
Intellectual Property Assessment of Batik Artisans Works a Case Study in The Village of Wukirsari Imogiri Bantul. This study aimed to determine the intellectual property rights that can be granted on the work of batik artisans in Imogiri, to know constraints found in protecting intellectual property rights to the works of batik artisans in Imogiri, and to know the efforts that have been made to overcome these constraints. Descriptive study with a qualitative approach, interviews, osbervasi, and documentation selected as data collection techniques. Seven research subjects are determined by the snowball technique. The analysis of the data in the form of domain analysis, taxonomic analysis, komponensial analysis, and theme analysis. The conclusions of this study is that the intellectual property rights (IPR) which can be used to protect the work of batik artisans in Imogiri are: 1) copyright; 2) simple patent; 3) the right brand, and 4) geographical indication rights. The constraints in the provision of IPR protection over the work of batik artisans in Imogiri are: 1) lack of knowledge and understanding of the batik artisans in Imogiri on IPR; 2) the strong culture of togetherness makes it very difficult for artisans to accept IPR concepts that highlight the personal rights and 3) The IPR provisions in commercial and profit-oriented economic incompatible with the values held by artisans, and 4) the high cost and difficulty of obtaining IPR procedures.
\end{abstract}

Keywords: intellectual property rights, batik works, batik artisans women 


\section{PENDAHULUAN}

Sebagai konsekuensi dari keikutsertaan pemerintah Indonesia sebagai negara peserta perjanjian pembentukan WTO, terutama yang terkait dengan perjanjian atau konvensi internasional di bidang Hak Kekayaan Intelektual (HKI), adalah dibuatnya regulasi tentang perlindungan terhadap karya intelektual manusia. Permasalahan tentang hak kekayaan intelektual di satu sisi berkait dengan masalah liberalisasi ekonomi, dan di sisi lain berhadapan dengan kondisi sosial, budaya, ekonomi masyarakat Indonesia. Kondisi sosial budaya masyarakat Indonesia masih berada dalam masa transisi masyarakat industrial dan belum semuanya mengerti dan memahami masalah-masalah HKI. Ini tidak dapat diingkari mengingat konsep mengenai hak milik atas kekayaan intelektual memang bukan berasal dari masyarakat Indonesia, melainkan berasal dari masyarakat negara-negara maju untuk melindungi karya-karya intelektual mereka yang notabene pola pikir masyarakat negara-negara tersebut berbeda dengan masyarakat Indonesia.

Keadaan ekonomi bangsa Indonesia yang masih berada jauh dari tingkat pendapatan perkapita masyarakat negara-negara maju, menjadi salah satu penyebab terkendalanya sebagian masyarakat Indonesia dalam memaknai dan memahami hak kekayaan intelektual serta regulasinya. Akibat dari ketidaktahuan terhadap peraturan-peraturan yang terkait dengan HKI tersebut acapkali masyarakat Indonesia terutama masyarakat industri kecil dirugikan, karena mereka dianggap melanggar ketentuan tentang HKI walaupun sebetulnya karya-karya yang mereka buat adalah hasil dari ciptaan mereka sendiri. Bahkan karena sebagian masyarakat Indonesia masih berada pada masyarakat transisi dari agraris ke masyarakat industri, dan karena pengaruh kultur dan agama, tidak jarang mereka beranggapan bahwa membagikan ilmu dan temuan mereka kepada orang lain merupakan perbuatan yang mulia. Wajarlah apabila kemudian keluguan dan "kemuliaan" hati tersebut dimanfaatkan secara tidak bertanggung jawab oleh pihak lain, yang berakibat karya dan temuan-temuan sebagian masyarakat Indonesia kemudian "dicuri" oleh orang lain.

Pada hakikatnya hak kekayaan intelektual merupakan hak yang timbul berdasarkan kerja intelektualitas, kreativitas, rasio, dan otak manusia karena telah memiliki ide atau gagasan mengenai sesuatu hal sehingga timbul hak-hak yang bersifat imateriil dan dapat diterima oleh nalar manusia. Oleh karena itu, dapat dikatakan bahwa HKI merupakan hak milik terhadap benda tidak berwujud yang berupa informasi, ilmu pengetahuan, teknologi, seni, sastra, ketrampilan, dan lain-lain yang tidak mempunyai bentuk tertentu (Ditjen HKI, 2005:26). Adapun ruang lingkup hak-hak yang tercakup dalam perlindungan HKI berdasarkan Hasil-hasil Perjanjian Putaran Uruguay pada Negosiasi Perdagangan Multilateral Annec $1 \mathrm{C}$ adalah sebagai berikut: a. Copyright \& Related Right (hak cipta dan hak-hak yang berkaitan dengan hak cipta); b. Trademarks (merek); c. Geographical Indication (indikasi geografis); d. Industrial Design (desain industri); e. Patens (paten); f. Lay out Design - Topographies - of Integrated Circuits (desain lay out dari lingkaran elektronik terpadu); g. Protection Undisclosed Information (perlindungan terhadap rahasia dagang); dan h. Control of Anti-Competititve Practices in Contractual Licences (pengendalian terhadap praktikpraktik persaingan tidak sehat dalam perjanjian lisensi. Ruang lingkup HKI ini cukup luas meliputi berbagai macam hak yang timbul dari adanya produk-produk hasil pemikiran manusia dan terus berkembang baik dari segi kualitas maupun kuantitas, sesuai dengan perkembangan kehidupan dan kreativitas manusia.

Ciri khas dari hak atas kekayaan intelektual adalah hak tersebut merupakan hak privat, sehingga seseorang bebas untuk mengajukan permohonan atau mendaftarkan karya intelektualnya atau tidak. Hak eksklusif yang diberikan oleh negara kepada individu pelaku HKI (inventor, pencipta, pen- 
desain, dan sebagainya) tiada lain dimaksudkan penghargaan atas hasil karya/kreativitasnya dan agar orang lain terangsang untuk dapat lebih lanjut mengembangkannya lagi, sehingga dengan sistem HKI tersebut kepentingan masyarakat ditentukan melalui mekanisme pasar. Sistem HKI juga menuntut diadakannya sistem dokumentasi yang baik atas segala bentuk kreativitas manusia, sehingga kemungkinan dihasilkannya teknologi atau hasil karya lainnya yang sama dapat dihindarkan atau dicegah. Dengan adanya dokumentasi yang baik ini diharapkan masyarakat dapat memanfaatkannya secara maksimal atau mengembangkannya lebih lanjut untuk memberikan nilai tambah yang lebih tinggi lagi.

Kepemilikan HKI sangat penting dalam menghadapi pasar global, karena dengan kepemilikan HKI seseorang telah memiliki kepastian hukum ketika ada pengusaha lain yang akan meniru dengan merek yang sama. Contoh akibat dari tidak segera didaftarkannya HKI oleh perusahaan/perajin adalah apa yang dikemukakan oleh Komaruddin Kadiya, perajin batik dari sentra industri Batik Trusmi Cirebon (Kompas, 15 September 2004) yang menyatakan bahwa banyak penjiplakan motif batik oleh para perajin dari negara-negara tetangga. Sehubungan dengan hal itu menurut Komarudin, mematenkan motif-motif batik merupakan hal yang harus segera dilakukan mengingat pula bahwa pematenan merupakan bentuk proteksi untuk kekayaan intelektual dan ciri khas daerah.

Negara Indonesia terkenal dengan batiknya yang cantik dan unik. Hampir semua daerah di Indonesia memiliki dan mengembangkan karya batik yang spesifik dengan motif-motif etnik tertentu, sehingga mudah untuk dikenali dari wilayah mana asal batik tersebut. Salah satunya adalah daerah Imogiri Kabupaten Bantul yang menghasilkan batik tulis dengan motif-motif tradisional dan diwarnai dengan pewarna alam. Di Imogiri banyak perempuan yang bekerja dengan menjadi perajin batik. Kegiatan perajin batik ini banyak tersentra di Desa Wukirsari Ke- camatan Imogiri Kabupaten Bantul Propinsi Daerah Istimewa Yogyakarta. Kerajinan batik Desa Wukirsari ini dikenal dengan nama "Batik Imogiri".

Karya-karya perajin batik Imogiri Bantul ini perlu dilindungi dengan hak kekayaan intelektual, mengingat dari karya, kreasi temuan bahan alami pewarna batik ini termasuk hasil ciptaan yang mempunyai nilai jual tinggi. Apabila tidak dilindungi dengan HKI, karya-karya ini dapat dicuri oleh orang lain. Bahkan apabila karya-karya ini kemudian didaftarkan oleh orang lain tersebut, bukan tidak mungkin para perajin ini malah diadukan sebagai pelanggar HKI, padahal merekalah yang menciptakan karya-karya dan ramuan-ramuan pewarna batik tersebut. Menurut Larasati Suliantara pada pameran batik di Galeri Batik Jawa Yogyakarta tanggal 1-31 Mei 2008 (Kompas Yogyakarta, 6 Mei 2008: C) pewarna alami mempunyai daya tarik internasional, dan batik yang menggunakan pewarna alami akan terlihat lebih lembut dibandingkan dengan batik yang menggunakan pewarna kimia yang terlihat lebih mencolok.

Tujuan yang ingin dicapai dalam penelitian ini adalah untuk mengetahui macam HKI yang dapat melindungi karya perempuan perajin batik Imogiri, mengidentifikasi kendala yang ditemukan dalam usaha memberikan hak kekayaan intelektual terhadap karya-karya perajin batik Imogiri, dan mengidentifikasi usaha yang telah dilakukan oleh pemerintah daerah maupun instansi terkait untuk mengatasi kendala-kendala tersebut. Hasil penelitian ini diharapkan dapat memberikan manfaat bagi: masyarakat, pelaku-pelaku industri termasuk industri kecil/UKM, home industry, dan para perajin batik berupa penyadaran mengenai belum cukup terlindunginya hak kekayaan intelektual atas karya-karya batik perajin batik Imogiri. Diharapkan selanjutnya pemerintah daerah ataupun instansi yang terkait dapat melakukan pembinaan, serta pendampingan terhadap para perajin batik dalam perlindungan hak kekayaan intelektual atas karya mereka, mengingat karya dan temuan mere- 
ka mempunyai nilai jual yang tinggi yang berpotensi meningkatkan taraf hidup dan perekonomian mereka.

\section{METODE}

Penelitian ini merupakan penelitian deskriptif dengan pendekatan kualitatif. Penelitian dilakukan dalam tiga tahap. Tahap pertama, melakukan orientasi dan eksplorasi, dengan latar penelitian perempuan perajin batik Imogiri di Desa Wukirsari Kecamatan Imogiri Kabupaten Bantul. Kedua, melakukan eksplorasi cakupan-cakupan HKI yang dapat diperoleh perempuan perajin batik untuk melindungi karya-karya mereka; upaya-upaya yang telah dilakukan untuk melindungi HKI karya perempuan perajin batik Imogiri, kendala-kendala yang dihadapi dalam upaya-upaya perlindungan HKI karya perempuan perajin batik Imogiri Bantul beserta usaha yang telah dilakukan untuk mengatasi kendala. Tahap ketiga melakukan member check atau mengecek hasil/temuan penelitian.

Data penelitian diperoleh melalui wawancara mendalam, observasi, dan dokumentasi. Wawancara mendalam dilakukan dengan mempergunakan pedoman wawancara terhadap subjek penelitian yang ditentukan secara snow ball. Sebagai subjek penelitian adalah Ketua Kelompok Perajin Batik Tulis yang merupakan informan awal, para perempuan perajin batik, dan seorang perajin yang mempunyai keahlian membuat desain batik dan dalam pewarnaan. Observasi dilakukan secara tidak terstruktur, antara lain untuk melihat secara langsung kreasi-kreasi batik karya para perajin, proses pembuatan dan proses pewarnaan batik. Analisis data dalam penelitian ini dilaksanakan dengan menggunakan: 1) analisis domain, 2) analisis taksonomis, 3) analisis komponensial, dan 4) analisis tema. Analisis domain digunakan secara simultan pada saat pengumpulan data dilapangan. Sedangkan analisis taksonomis dan komponensial dipergunakan pada pengumpulan data dilapangan pada tahap eksplorasi terfokus. Analisis tema dilakukan setelah ke- giatan pengumpulan data dan analisis data di lapangan. Untuk pencermatan kesahihan data pada tahap kegiatan pengumpulan data dan analisis data dilakukan dengan cara sebagai berikut: 1) penciptaan raport yang baik dengan para informan; 2) melakukan peer debriefing dengan teman sejawat; 3) melakukan member check, dan 4) melakukan triangulasi sumber data dan metode pengumpulan data.

\section{HASIL DAN PEMBAHASAN}

\section{Desa Wukirsari sebagai Sentra Batik Imogiri}

Desa Wukirsari merupakan salah satu desa di Kecamatan Imogiri, Kabupaten Bantul, Propinsi Daerah Istimewa Yogyakarta, Indonesia. Desa ini terletak di sebelah selatan Kota Yogyakarta dan memiliki luas wilayah lebih kurang 15 km persegi. Masyarakat desa Wukirsari adalah masyarakat yang bersifat komunal, sebagaimana masyarakat desa di Jawa umumnya, yang mengutamakan kebersamaan dalam menjalani kehidupan sehari-hari, diliputi oleh rasa guyub, yang sudah mengintegrasi dalam setiap warga. Hal ini relevan dengan pendapat Koentjaraningrat (1983:62) yang menyatakan bahwa konsep gotong royong merupakan suatu konsep yang erat bersangkut paut dengan kehidupan rakyat dalam masyarakat agraris. Semangat tolong menolong tampak dalam aktivitas kehidupan sehari-hari maupun dalam kegiatan-kegiatan yang bersifat budaya religius.

Semangat tolong menolong muncul dalam berbagai bentuk kegiatan, antara lain njurung (bahasa Jawa) yakni keterlibatan kerabat dan warga desa pada saat salah seorang warga desa menyelenggarakan perhelatan sunatan, perkawinan, atau upacara adat lainnya. Selain itu, juga tampak aktivitas secara spontan tanpa permintaan dan tanpa pamrih untuk membantu ketika salah seorang warga mengalami musibah, kematian, sakit, atau bencana lainnya, yang lazim di- 
sebut tetulung atau layat (bahasa Jawa). Kegiatan yang diwarnai dengan semangat tolong menolong ini tidak terlepas dari karakter religius masyarakat yang dipengaruhi oleh nilai-nilai keagamaan, khususnya agama Islam, seperti pada kegiatan: (1) Mudo Palupi, yakni pembacaan syair shalawat yang dilakukan oleh generasi muda; (2) Majemukan, yakni kegiatan yang dilakukan oleh masyarakat dalam rangka mensyukuri hasil panen dari ladang atau sawah mereka, yang dilakukan setelah panen raya setiap setahun sekali; (3) Nyadran, yakni upacara adat yang dilakukan masyarakat dalam rangka mendoakan arwah nenek moyang atau anggota keluarga yang telah meninggal; (4) Wali Kutuban, yakni kegiatan untuk mengawali tahun baru Jawa dan Islam, tepatnya pada tiga malam pertama bulan Suro (Muharram); dan sebagainya.

Desa Wukirsari terkenal sebagai salah satu sentra batik tulis tradisional di Indonesia, karena sudah memproduksi batik sejak beratus tahun yang lalu. Batik tulis yang diproduksi oleh para pembatik desa Wukirsari lebih dikenal sebagai batik Imogiri. Asal usul batik Imogiri berawal dengan keberadaan makam raja-raja di Imogiri yang terletak di bukit Merak pada tahun 1654. Untuk memelihara dan menjaga makam raja-raja tersebut, Keraton Yogyakarta menugaskan abdi dalem yang berasal dari daerah sekitar makam tersebut. Karena para abdi dalem penjaga makam tersebut sering berhubungan dengan keraton, maka kepandaian membatik dengan motif batik halus keraton pun menjadi berkembang di wilayah tersebut. Kemudian, keterampilan membatik tersebut diwariskan kepada anak atau cucu perempuan mereka.

\section{Proses Pembuatan dan Motif Batik Imogiri}

Sampai saat ini para perajin batik Imogiri tetap mempertahankan tradisi batik tulis. Para perajin berusaha tidak tergoda dan bertekad untuk tetap mempertahankan tradisi leluhur mereka, yaitu memproduksi batik tulis, bukan batik cap. Meskipun demikian, diakui bahwa mempertahankan prinsip ini memang berat, mengingat keuntungan memproduksi batik cap lebih besar dari pada batik tulis, karena batik tulis tidak dapat diproduksi secara massal, dan biaya produksi batik tulis relatif besar, karena harus dikerjakan satu persatu dengan tahap-tahap yang njlimet (bahasa Jawa) atau sangat rumit dan rinci. Hal ini menyebabkan harga batik tulis relatif lebih mahal dan waktu penjualan menjadi lebih lama, karena kebanyakan konsumen lebih tertarik untuk membeli batik cap atau printing yang harganya jauh lebih murah. Adapun jenis-jenis batik tulis Imogiri yang diproduksi antara lain: jarit, sarung, dan selendang.

Proses pembuatan batik tidaklah sederhana, dan tidak dapat dikerjakan seorang diri. Tahapan yang harus dilalui dalam proses pembuatan batik Imogiri antara lain: pemilihan kain dan pelemasan atau pencucian kain yang sering disebut dengan istilah gemplong dan ngethel; membuat gambar (pola) atau mola; ngengreng atau pelilinan; nembok yang prosesnya hampir sama dengan nglowong tetapi menggunakan malam yang lebih kuat untuk menahan rembesan zat warna biru atau coklat; pewarnaan yang sering di sebut medel mempergunakan pewarna alam seperti daun, kayu kliko, daun tom, kulit kayu mahoni, kayu jambal, soga, tegeran, pace atau mengkudu dan lain sebagainya; menghilangkan lilin atau ngerok; mbironi yakni proses yang dilakukan untuk mempertahankan warna biru; nyoga yakni memberi warna coklat dengan ramuan kulit kayu soga, tingi, tegeran dan lain-lain; mbabar atau nglorot, yaitu membersihkan malam; dan tahap terakhir mencuci kain dan diangin-anginkan suapaya kering. 
Adapun sebagian motif batik Imogiri klasik yang berhasil dikumpulkan dalam penelitian ini adalah: Cuwiri, Sido Asih Kemoda Sungging, Kembang Temu Latar Putih, Tambal Kanoman, Prabu Anom/ Parang Tuding, Semen Romo Sawat Gurdo Cantel, Sido Mukti Luhur, Parang Bligon, Ceplok Nitik Kembang Randu, Parang Curigo, Ceplok Kepet, Parang Kusumo, Ceplok Mangkoro, Latar Putih Cantel Sawat Gurdo, Sido Asih Sungut, Sido Asih, Parang Grompol, dan Trumtun Sri Kuncoro. Motif lain yang didapatkan dalam penelitian ini adalah: Wahyu Tumurun, Tritik Jumputan, Semen Gurdo, Udan Liris, Sido Asih, Parang Nitik, Peksi Kurung, Nogo Gini, Sekar Manggis, Jalu mampang, Sekar Polo, Sekar Keben, Lung Kangkung, Sekar Asem, Semen Kuncoro, Harjuno Manah, Sapit Urang, Semen Mentul Grompol, dan Nogosari. Kebanyakan batik tulis Imogiri dibuat dengan motif-motif tradisional menggunakan pewarna soga dan wedel yang menghasilkan warna coklat tua dan biru pekat dengan dasar kain berwarna tetap putih atau coklat.

\section{Hak Kekayaan Intelektual dan Per- lindungan Karya Perempuan Perajin Batik Imogiri}

Batik tulis Imogiri memiliki kekhasan pada jenis, motif, dan warnanya, yang pada awalnya relatif tidak berkembang dan minim kreativitas. Sejak ada pesanan dan permintaan dari pasar untuk memodifikasi dan mengembangkan motif tradisional, maka motif batik Imogiri menjadi lebih hidup dan kaya variasi. Tema atau motif batik Imogiri banyak terinspirasi oleh flora dan fauna yang terdapat di sekitar rumah, sehingga motif seperti kembang kantil, kembang senandung alit, daun lumbu atau lompong, daun asem jawa, dan daun pepaya mulai dimasukkan sebagai motif batik tulis. Terkadang motif ciptaan pendesain tidak lazim dan tidak mengacu pada pakem motif batik klasik, sebagai con- toh ciptaan bahan kemeja batik dengan gambar laba-laba besar, kapal nelayan atau bunga matahari dan lotus sebagai gambar utama. Pada saat World Cup 2010 lalu, diciptakan batik dengan motif bola sebagai gambar utama sedangkan untuk isen-isen tetap dimasukkan unsur motif tradsional, agar tidak kehilangan kekhasan sebagai batik Imogiri. Suasana dan area kompleks makam raja-raja Imogiri juga telah memberi inspirasi sehingga tercipta motif-motif baru seperti batik tulis motif gentong atau enceh, ukiran kayu, dan motif gapura makam yang sangat "khas Imogiri".

Hampir semua motif batik Imogiri tidak pernah didokumentasikan dalam bentuk soft copy, meskipun ada yang diujudkan dalam hard copy, yakni digambar di atas kertas tipis. Kebanyakan motif batik tersebut digambarkan langsung ke atas kain, kemudian di-ngengreng atau dimalam oleh perajin lainnya. Para perajin tidak merasa perlu menyimpan, mendokumentasikan, dan merahasiakan motif rancangannya yang terkadang memerlukan "ekstrakreativitas" dalam proses penciptaannya. Mereka tidak mempermasalahkan karya-karya mereka yang ditiru orang lain, terkadang malah mereka, bangga ketika mereka tahu karya mereka ditiru orang lain. Bagi mereka lebih baik karya batik mereka terjual cepat untuk memenuhi kebutuhan sehari-hari, daripada memikirkan karya mereka dijiplak atau tidak.

Pewarnaan batik tulis Imogiri menggunakan pewarna alam yang awalnya dipakai secara turun temurun dan tidak diketahui siapa penciptanya. Namun, sejak terbentuknya kelompok-kelompok perajin batik Imogiri dan ada pendampingan dari Yogyakarta-Central Java Community Assistance Program yang diketuai Larasati Suliantara, mereka semakin konsisten mempergunakan pewarna alam. Hasil dari pewarnaan alam jauh berbeda dengan pewarna kimia, karena pewarna alam menghasilkan warna- 
warna yang soft, lembut, dan tidak akan menyala. Jenis batik ini banyak diminati oleh wisatawan asing. Dengan pewarna alam yang khas, juga berhasil diproduksi batik lawasan, atau batik yang terkesan sebagai batik yang sudah lama. Keunikan lain dari pewarna alam adalah dari proses pencelupan/pewarnaan yang sama, tidak akan dihasilkan batik dengan warna yang persis sama.

Menilik paparan di atas, sebetulnya ada beberapa perlindungan hukum HKI yang bisa diterapkan terhadap kreasikreasi para perajin batik tulis Imogiri. Perlindungan hukum ini bisa masuk di dalam kategori perlindungan HKI dalam berbagai macam maupun ruang lingkup HKI, bahkan satu produk sekaligus bisa dilindungi oleh berbagai hak yang tercakup dalam hak kekayaan intelektual. Cakupan HKI yang bisa melindungi karya-karya perempuan perajin batik Imogiri di antaranya adalah:

a. Hak cipta untuk desain motif batik yang baru, yang tidak merupakan modifikasi motif lama. Hal ini mengacu pada ketentuan Pasal 12 ayat 1 huruf i UU No. 19 Tahun 2002 tentang Hak Cipta dengan berbagai peraturan pelaksanaannya. Kreasikreasi dan ciptaan perajin batik dapat dilindungi oleh hak cipta, mengingat salah satu lingkup perlindungan hak cipta, di antaranya adalah seni batik. Dengan dilindunginya karya/ motif batik Imogiri tersebut, akan muncul hak eksklusif bagi perajin/ pencipta untuk mempublikasikan atau memperbanyak sendiri motif batik baru yang menjadi ciptaannya atau memberi ijin kepada pihak lain untuk itu. Sebetulnya perlindungan suatu ciptaan timbul secara otomatis sejak ciptaan diwujudkan dalam bentuk yang nyata, yakni berupa motif batik baru yang merupakan kreasi dari perajin dan tidak sekedar sebagai hasil memodifikasi unsur motif batik lama, karena pendaf- taran suatu ciptaan tidak merupakan suatu kewajiban. Namun demikian, pendaftaran motif batik tersebut tetap dibutuhkan, agar perajin batik sebagai pencipta memperoleh "surat pendaftaran ciptaan" yang sangat urgen apabila perajin bermaksud untuk membuat perjanjian lisensi atau perjanjian pengalihan hak cipta kepada orang lain. Surat pendaftaran ciptaan juga dapat dijadikan sebagai alat bukti awal di pengadilan apabila timbul sengketa dikemudian hari atas motif batik tersebut. Untuk mempermudah proses pendaftaran, sebaiknya memang para perajin tersebut mendokumentasikan semua motif batik rancangannya dalam bentuk soft copy, ataupun dalam bentuk hard copy;

b. Hak paten sederhana, terutama kreasi dalam pencelupan dan pewarnaan batik. Ini dikarenakan proses pembuatan pencelupan dan pewarnaan batik terutama dengan bahan-bahan pewarna alami walaupun dilakukan dengan menggunakan teknologi sederhana, namun mempunyai nilai tinggi dan menghasilkan tata warna yang unik dan khas yang juga merupakan lingkup perlindungan paten. Agar dapat dilindungi dengan hak paten, harus dibuat suatu formula khusus proses pewarnaan batik alam yang akurat dan konsisten, mengingat takaran-takaran yang dipergunakan perajin batik Imogiri dalam mencampur bahan pewarna alam, menggunakan ukuran-ukuran yang kurang terjamin tingkat akurasinya, misal: dengan memakai ukuran "segenggam", "seikat", "sesendok", dan sebagainya. Agar dapat diterapkan dalam suatu proses industri, para perajin dengan pendampingan dapat menyusun langkah-langkah pewarnaan secara detail dan mempergunakan takaran-takaran yang akurat, misalnya: dengan memakai 
dacin, timbangan, gelas ukur, dan sebagainya;

c. Hak merek juga dapat diberikan pada hasil karya para perajin batik Imogiri. Merek ini merupakan suatu "tanda" yang berupa gambar, nama, kata, huruf-huruf, angka-angka, susunan warna atau kombinasi dari unsur-unsur tersebut yang memiliki daya pembeda dan digunakan dalam kegiatan perdagangan. Fungsi merek, yaitu sebagai: tanda pengenal untuk membedakan hasil produksi yang dihasilkan seseorang atau beberapa orang secara bersama-sama atau badan hukum dengan produksi orang lain atau badan hukum lainnya; alat promosi, sehingga mempromosikan hasil produksinya cukup dengan menyebut mereknya; jaminan atas mutu barangnya; penunjuk asal barang/jasa yang dihasilkannya, inilah yang sering dikenal dengan indikasi geografis. Kreasi perajin batik Imogiri bisa dilindungi oleh hak merek, yakni merek dagang, apabila mereka mendaftarkan kreasinya itu ke Ditjen HKI dengan menggunakan merek tertentu. Namun demikian, karena keterbatasan pengetahuan dan kesederhanaan berpikir, mereka membuat tanda pengenal yang selanjutnya difungsikan sebagai "merek dagang" terhadap produksi batik Imogiri sesuai dengan nama paguyuban/ kelompok perajin tempat mereka bergabung dan menjadi anggota. Penggunaan "Wahyu Tumurun", "Sidomukti", dan motif batik lainnya sebagai merek dagang akan ditolak oleh Ditjen HKI, karena nama-nama tersebut telah menjadi milik umum, yakni merupakan motif batik tradisional yang sudah dimiliki secara turun temurun dan oleh UNESCO telah dinyatakan sebagai warisan batik Indonesia. Oleh karena itu, agar batik Imogiri dapat dilindungi dengan merek dagang tertentu, harus dipilih nama lain dan bukan mempergunakan motif batik sebagai merek dagang.

d. Hak atas indikasi geografis karena pada kreasi-kreasi mereka dapat menunjukkan ciri-ciri tertentu yang hanya dipunyai dan hanya ada pada batik Imogiri. Hak atas Indikasi geografis adalah suatu tanda yang menunjukkan daerah asal suatu barang yang karena faktor lingkungan geografis termasuk faktor alam, faktor manusia, atau kombinasi dari kedua faktor tersebut memberikan ciri dan kualitas tertentu pada barang yang dihasilkannya. Sebagai contoh, motif batik berwarna biru kehitaman yang ditimbulkan dari pewarna wedel pada kain berdasar putih, merupakan warna khas batik Imogiri. Demikian juga batik dengan motif-motif gentong, gapura makam raja-raja, atau batik dengan motif anak tangga pada kompleks makam raja-raja yang dimodifikasi sedemikian rupa sehingga menjadi motif batik yang artistik, menunjukkan Imogiri sebagai daerah asal atau indikasi geografis dari kreasi batik tersebut sehingga untuk motif-motif batik tertentu yang sangat "khas Imogiri" dapat didaftarkan ke Ditjen HKI untuk memperoleh perlindungan hak atas indikasi geografis.

\section{Kendala dalam Perlindungan HKI Karya Perajin Batik Imogiri}

Kebanyakan para perajin batik Imogiri belum menganggap perlindungan HKI sebagai suatu kebutuhan dan mereka belum memandang urgen terhadap perundang-undangan di bidang HKI. Beberapa kendala dalam pemberian perlindungan hak kekayaan intelektual terhadap karya perajin batik Imogiri antara lain adalah:

a. Terbatasnya pengetahuan dan pemahaman para perajin batik Imogiri mengenai hal-hal yang berkaitan 
dengan hak kekayaan intelektual yang sebetulnya diperlukan dan dapat melindungi karya batik mereka.

b. Rendahnya tingkat pendidikan dan tingkat perekonomian para perajin menghambat perlindungan HKI atas karya perajin. Kebanyakan para perajin batik hanya lulus sekolah dasar, dan mengawalinya sebagai buruh batik, yakni menerima kain dan malam/lilin untuk membatik dari para pengusaha batik, kemudian menyetorkan hasil mereka kepada para pengusaha tersebut. Ketergantungan para perajin kepada para pengusaha menyebabkan kondisi ekonomi para perajin tidak pernah bergulir menjadi lebih kuat. Rendahnya tingkat pendidikan dan perekonomian itulah yang membuat para perajin berpikiran "praktis" dan sederhana, yakni lebih memilih karya batiknya terjual cepat untuk memenuhi kebutuhan sehari-hari daripada memikirkan karya mereka dijiplak, dicuri, dan sebagainya. Para perajin tidak terlalu merespons terhadap gagasan HKI untuk memberi perlindungan atas karya-karya mereka.

c. KI HKI HKUIHKBudaya komunal dan religius, membuat para perajin sangat sulit menerima konsepkonsep HKI yang menonjolkan hakhak pribadi. Bagi Menurut para perajin, proses pembuatan dan motif tradisional batik adalah merupakan warisan budaya, yang tidak selayaknya dikuasai secara possessive (dimonopoli). Falsafah hidup dalam kebersamaan membuat tradisi "berbagi" termasuk berbagi pengetahuan tentang batik, merupakan salah satu bentuk kebajikan, yang imbalannya adalah kepuasaan batiniah. Ini berbeda dengan pandangan masyarakat Barat, tempat asal mula berkembanganya hak kekayaan intelektual, yang menempatkan gagasan, perasaan, pengetahuan bahkan perasaan sebagai suatu kekayaan bernilai uang (intellectual property). Perajin batik tidak memandang pengetahuan mereka terhadap design dan motif batik tradisional sebagai kekayaan (intellecual property) yang dapat dimiliki secara individual. Karena masyarakat lokal tidak memahami konsep abstrak dalam bentuk pemilikan individual atas suatu warisan budaya atau atas suatu pengetahuan.

d. Ketentuan-ketentuan dalam HKI yang bersifat individualistik, komersial, dan berorientasi pada aspek material, khusunya keuntungan ekonomis dari pemanfaatannya tidak dikenal dan tidak sesuai dengan nilai-nilai komunalistik yang dimiliki para perajin batik Imogiri. Para perajin memandang proses pembuatan batik adalah pengetahuan tradisional, dan bukan merupakan property yang mempunyai nilai komersial, melainkan lebih sebagai cultural heritage, yang mengandung nilai-nilai dan filosofi yang dalam. HKI adalah sesuatu yang abstrak, sedangkan para perajin adalah bagian dari masyarakat lokal yang berpikir kongkret dan sederhana. Untuk dapat mendapatkan perlindungan paten, diperlukan langkah-langkah yang rumit, seperti penyusunan spesifikasi paten, klaim, dan lain-lainnya, yang kesemuanya itu sangat asing bagi para perajin. Selain itu, untuk memperoleh perlindungan paten, diperlukan biaya yang relatif tidak sedikit, baik untuk membayar annual fee, biaya pemeliharaan paten (yang apabila tidak dibayarkan, hak paten yang bersangkutan akan dianggap batal demi hukum), biaya konsultan, dan sebagainya. Semua itu akhirnya menjadi faktor-faktor yang menghambat para perajin untuk dapat memperoleh perlindungan HKI atas pengetahuan tradisional mereka. 
e. Beberapa perajin yang sudah pernah mendapatkan sosialisasi tentang hak kekayaan intelektual menyatakan bahwa prosedur pengajuan permohonan HKI sulit dan mahal. Prosedur pengajuan permohonan HKI dirasa sulit dan mahal. Perlindungan HKI diperoleh harus melalui upaya-upaya tertentu sesuai dengan ketentuan perundang-undangan HKI. Prosedur pendaftaran atau pengurusan untuk mendapatkan perlindungan HKI yang tidak sederhana dan beban biaya yang tidak sedikit membuat "tawaran perlindungan HKI" tersebut tidak cukup menarik minat para perajin untuk mendapatkannya.

\section{SIMPULAN}

Di penghujung tulisan ini dapat dikemukakan beberapa simpulan sebagai berikut:

1. Hak kekayaan intelektual yang bisa diterapkan terhadap kreasi-kreasi para perajin batik tulis Imogiri, antara lain:

a. Hak cipta terhadap hasil karya para perajin batik Imogiri merupakan hasil pengembangan desain motif batik yang baru, bukan merupakan modifikasi motif lama;

b. Hak paten sederhana juga dapat diterapkan pada karya perajin batik Imogiri, karena hasil-hasil karya perempuan perajin batik Imogiri, terutama kreasi dalam pencelupan dan pewarnaan batik dengan bahanbahan pewarna alami, walaupun dilakukan dengan menggunakan teknologi sederhana, mempunyai nilai tinggi dan menghasilkan tata warna yang unik dan khas;

c. Walaupun sampai saat ini hasil produksi perajin batik Imogiri belum diberi merek sesuai dengan ketentuan UU No. 15 Tahun 2001 tentang Merek, para perajin masih mempergunakan motif-motif batik seperti: sidomukti, sidoluhur, dan wahyu tumurun sebagai "merek dagang". Penggunaan motif batik sebagai merek dagang akan ditolak oleh Ditjen HKI, karena nama-nama tersebut telah menjadi milik umum, yakni merupakan motif batik tradisional yang sudah dimiliki secara turun temurun dan oleh UNESCO dinyatakan sebagai warisan batik Indonesia. Agar batik Imogiri dapat dilindungi dengan merek dagang, harus dipilih nama lain dan bukan mempergunakan motif batik sebagai merek dagang;

d. Hak indikasi geografis juga dapat diberikan, sepanjang kreasi-kreasi perajin tersebut dapat menunjukkan ciri-ciri tertentu yang hanya dipunyai dan hanya ada pada batik Imogiri. Sebagai contoh, motif batik berwarna biru kehitaman yang ditimbulkan dari pewarna wedel pada kain berdasar putih, merupakan warna khas batik Imogiri. Demikian juga batik dengan motif-motif gentong atau enceh, gapura makam raja-raja atau batik dengan motif anak tangga pada kompleks makam raja-raja yang dimodifikasi sedemikian rupa, menunjukkan Imogiri sebagai daerah asal atau indikasi geografis dari kreasi batik tersebut. Karena itu, untuk motif-motif batik yang sangat "khas Imogiri" tersebut dapat didaftarkan ke Ditjen HKI untuk memperoleh perlindungan hak indikasi geografis.

2. Beberapa kendala dalam pemberian hak kekayaan intelektual terhadap kreasikreasi para perajin batik Imogiri, di antaranya adalah sebagai berikut:

a. Terbatasnya pengetahuan dan pemahaman para perajin batik Imogiri tentang HKI yang dapat melindungi karya-karya mereka;

b. Rendahnya tingkat perekonomian para perajin batik Imogiri;

c. Kuatnya budaya komunal masyarakat desa Wukirsari membuat para perajin sangat sulit menerima konsepkonsep HKI yang menonjolkan hakhak pribadi; 
d. Para perajin memandang dalam motif batik terkandung nilai-nilai dan filosofi yang dalam, sehingga bukan merupakan property yang mempunyai nilai komersial;

e. Sulit dan mahalnya melewati prosedur pengajuan permohonan $\mathrm{HKI}$

\section{DAFTAR PUSTAKA}

Agus Sardjono. (2009). Membumikan HKI di Indonesia. Bandung: Nuansa Aulia.

Anonim. (2004). Batik Indonesia Sulit Dipatenkan, Banyak Dijiplak. www kompas. com, diakses tanggal 19 April 2008.

Anonim. (2004). Lima UKM Pekalongan Terima HAKI, www.infohaki.com, diakses tanggal 19 April 2008.

Direktorat Jendral Hak Kekayaan Intelektual. (2005).Buku Panduan Hak Kekayaan Intelektual. Tangerang: Departemen $\mathrm{Hu}-$ kum dan HAM Republik Indonesia.

Harian Kompas. 6 Mei 2008. Hal C Yogyakarta.
Hikmahanto Juwana. (2006). Arah Kebijakan Pembangunan Hukum Di Bidang Perekonomian dan Investasi. Disampaikan pada seminar arah pembangunan Hukum menurut UUD 1945 hasil amandemen yang diadakan BPHN tanggal 29-31 Mei 2006 di Jakarta.

Koentjaraningrat. (1983). Kebudayaan Mentalitet dan Pembangunan. Jakarta: Gramedia.

Kompas Cetak Cirebon Wednesday, 15 September 2004 diakses dari internet tanggal 19 April 2008, jam : 19.00 WIB.

Muhamad Djumhana. (2006). Perkembangan Doktrin dan Teori Perlindungan Hak Kekaayaan Intelektual. Bandung: Aditya Bakti.

Sanapiah Faisal. (1990). Penelitian Kualitatif Dasar-dasar dan Aplikasi. Malang: YA 3.

Tomi Suryo Utomo. (2010). Hak Kekayaan Intelektual di Era Global. Yogyakarta: Graha Ilmu. 